\title{
Future Academic Teachers' Digital Skills: Polish Case-Study
}

\author{
Nataliia Demeshkant \\ Institute of Educational Sciences, Pedagogical University of Cracow, Poland \\ Received March 27, 2020; Revised May 4, 2020; Accepted May 27, 2020
}

Copyright (C2020 by authors, all rights reserved. Authors agree that this article remains permanently open access under the terms of the Creative Commons Attribution License 4.0 International License

\begin{abstract}
Preparing quality academic teachers for modern digital native students is an essential task for higher educational institutions. Professional teachers' digital competencies combine professional, pedagogical, and technological knowledge and skills as well as beliefs regarding integrating technology in teaching practice. This article is an attempt to study the personal level of digital competence of PhD students as future academic teachers. The paper presents statements from an ongoing study $(\mathrm{n}=120)$ piloting large scale longitudinal qualitative teachers' surveys between 2017 and 2020. The first part of the research started in 2017 to attempt to recognize the personal level of digital competence of $\mathrm{PhD}$ students as future academic teachers. The study was conducted during 2017-2018 at the Wroclaw University of Environmental and Life Sciences. To study the levels of digital competence, a special questionnaire based on the European Competency Framework for the Digital Competence of Educators was used. The study results show different levels of digital competence depending on the students' field of study and specialty. The highest technological scores were demonstrated by $\mathrm{PhD}$ students of engineering specializations. However, the results also showed that on average PhD students do not feel well prepared for the practical use of digital techniques in teaching activities. The preliminary study results indicate the need to improve $\mathrm{PhD}$ training programs including various ways of developing students' skills for making better use of digital technology for teaching and learning.
\end{abstract}

Keywords PhD Students, Teacher Training, Digital Competencies, Poland

\section{Introduction}

Nowadays one of the main teachers' skills is to be able to integrate information and communication technology (ICT) into teaching. Besides the skills for how to teach subjects effectively, teachers should also know how to integrate digital technology into their teaching $[3,18]$. The opportunities provided by ICT (e.g. networking, interaction, information retrieval, presentation, and analysis) are seen as core elements in honing $21^{\text {st }}$-century skills. This also required a more comprehensive embedding of ICT and its pedagogical use in the curriculum for students as well as in teacher training. The teaching staff is the key player in strengthening and fostering the new digital environment in schools. A lot of recent studies highlighted the importance of digital competencies for in-service teachers of different levels [8, 23, 24,]. Because teacher professions are faced with rapidly changing requirements, teachers require an ever broader and more sophisticated set of competencies than before. Good teaching is not only effective behaviorally but must also reset on a foundation of adequately grounded premises [16].

\subsection{Digital Competencies of Teachers}

Innovating and modernizing education and training are key priorities for the majority of educational systems [15]. The key challenge for research and policy is to make sure that the full potential of digital technologies is used for learning and that effective digital-age learning is made possible through systemic and holistic change [7]. In particular, the ubiquity of digital devices causes the teachers must not only be digitally competent themselves, but must also promote students' digital competence and take advantage of digital technologies for enhancing and innovating teaching. Thus digital competencies specific to the teaching profession include educators' pedagogic and professional competencies as well as learners' competencies. (Figure 1). 


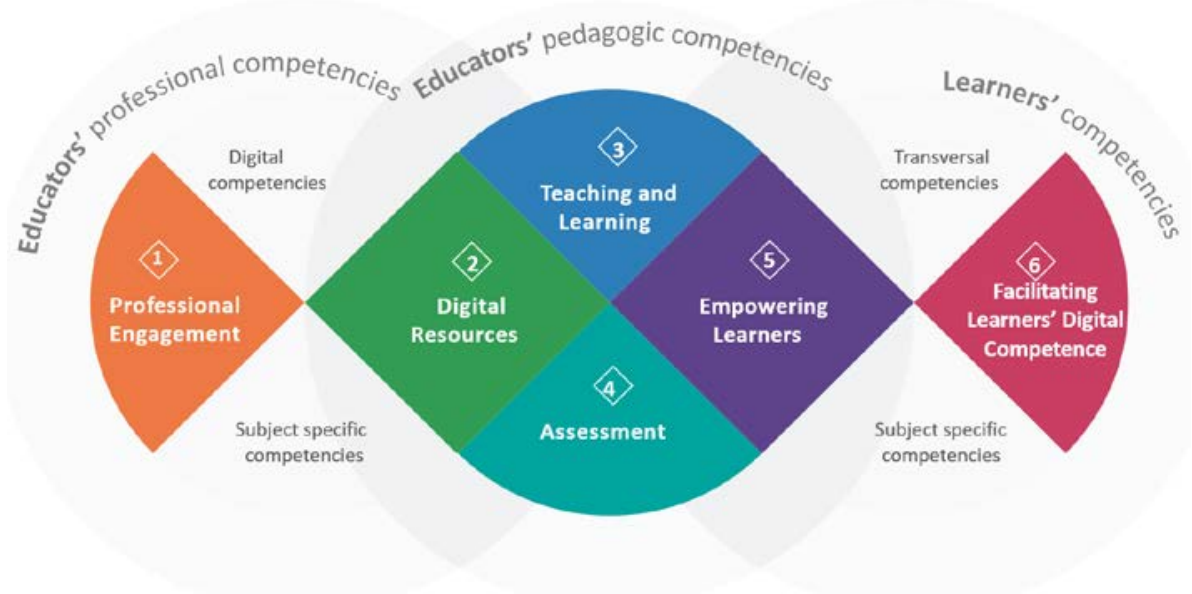

Figure 1. Digicompedu in a nutshell (according to the European Framework for the Digital Competence of Educators, 2017)

Professional teachers' digital competencies are seen as a combination of professional, pedagogical, and technological knowledge and skills [19], but also the ability to apply learning outcomes as is appropriate to the context [6]. A lot of authors highlight the role of teachers' personal pedagogical beliefs regarding whether and how to integrate technology within their classroom practices [9, 10]. Educators are role models for the next generation, that is why they need to be able to demonstrate their digital competence to learners and to pass on their creative and critical use of digital technologies [7]. Each level teachers need, in addition to the general digital competencies for life and work, educator-specific digital competencies to be able to effectively use digital technologies for teaching. Effective science and practical communication, which ensures an efficient flow of information about use of the new teaching and learning digital techniques, has a direct impact on the development of each scientific direction, practical introduction of the scientific results and to improve teacher professional development. According to the study conducted recently by Polish scientists, there are three areas of professional-pedagogical digital competence of teachers that should be developed to make progress with digitalization in Polish schools: subject-matter, methodological and technological competencies [2]. Effective teachers possess a sophisticated knowledge base, wherein content, pedagogy, and technology interplay in high degrees [17]. During the last few years, Polish universities have been making conscientious efforts to improve the educational process with modern digital teaching and learning methodology [2]. In spite of this, there is a scarcity of studies related to digital competence of $\mathrm{PhD}$ students.

\subsection{The Aim}

The purpose of this research has been to study the levels of digital competencies of $\mathrm{PhD}$ students as future academic teachers. The main objective was focused on the curricula and educational teacher training programs of $\mathrm{PhD}$ students taking into consideration the importance of their adequate professional training programs. The main objective was also focused on the ways of supporting and encouraging $\mathrm{PhD}$ students in using digital tools to enhance and innovate education.

The research was conducted by a team of Cracow Pedagogical University and the Wroclaw University of Environmental and Life Sciences researchers eager to better understand how digital technologies can be used to enhance and innovate education and training in their institutions.

\section{Materials and Methods}

The present study reports the first data or rather statements from an ongoing study $(\mathrm{n}=120)$ piloting large scale longitudinal research between 2017-2020. The first part of the research started in 2017 to attempt to recognize the personal level of digital competence of $\mathrm{PhD}$ students as future academic teachers.

\subsection{Methodology}

To achieve research goals, the analysis of the surveys was carried out. PhD students of different specializations of the Wroclaw University of Environmental and Life Sciences (Poland) were examined (Table 1). 
Table 1. Overview of returns by the respondents

\begin{tabular}{|c|c|}
\hline Specialization & $\boldsymbol{N}$ of the PhD students \\
\hline Animal Sciences & 24 \\
\hline Plant Sciences & 26 \\
\hline Veterinary Medicine & 22 \\
\hline Biotechnology & 25 \\
\hline Environmental Engineering & 23 \\
\hline total & $\mathbf{1 2 0}$ \\
\hline
\end{tabular}

The study survey was designed using the questionnaire for self-reflection, based on European Competency Framework for the Digital Competence of Educators [7]. According to the DigCompEdu questionnaire, there are twenty-two educator-specific digital competencies organized in six areas that are focused on different aspects of educators' professional activities (Table 2). The Framework also proposes a progression model to help educators assess and develop their digital competence. It outlines six different stages through which an educator's digital competence typically develops (Table 3).

Table 2. Areas of educator-specific digital competence

\begin{tabular}{|c|c|}
\hline Area & Description \\
\hline $\begin{array}{l}\text { I. Professional } \\
\text { Engagement }\end{array}$ & $\begin{array}{lcr}\text { Using digital } & \begin{array}{c}\text { technologies } \\
\text { collaboration }\end{array} & \begin{array}{r}\text { for } \\
\text { and }\end{array} \\
\text { professional development } & & \end{array}$ \\
\hline II. Digital Resources & $\begin{array}{l}\text { Sourcing, creating and sharing digital } \\
\text { resources }\end{array}$ \\
\hline & $\begin{array}{l}\text { ng the use of digital } \\
\text { nd learning }\end{array}$ \\
\hline IV. Assessment & $\begin{array}{l}\text { al technologies and strategies to } \\
\text { sessment }\end{array}$ \\
\hline $\begin{array}{l}\text { V. Empowering } \\
\text { Learners }\end{array}$ & $\begin{array}{l}\text { Using digital technologies to enhance } \\
\text { inclusion, } \\
\text { personalization and learners active } \\
\text { engagement }\end{array}$ \\
\hline $\begin{array}{l}\text { VI. Facilitating } \\
\text { Learners’ Digital } \\
\text { Competence }\end{array}$ & $\begin{array}{l}\text { Enabling learners to creatively and } \\
\text { responsibly use digital technologies for } \\
\text { information, communication, content } \\
\text { creation, wellbeing and problem-solving }\end{array}$ \\
\hline
\end{tabular}

Source: [7]
Table 3. Stages of educator's digital competence

\begin{tabular}{|c|l|}
\hline Stage & \multicolumn{1}{|c|}{ Description } \\
\hline $\begin{array}{c}\text { Newcomer } \\
\text { (A1) }\end{array}$ & $\begin{array}{l}\text { has an opportunity to begin enhancing his/her } \\
\text { skills with digital technology. }\end{array}$ \\
\hline Explorer (A2) & $\begin{array}{l}\text { is aware of the potential of digital technologies } \\
\text { and is interested in exploring them to enhance } \\
\text { pedagogical and professional practice. }\end{array}$ \\
\hline Integrator (B1) & $\begin{array}{l}\text { experiments with digital technologies in a variety } \\
\text { of contexts. Should be eager to expand his/her } \\
\text { repertoire of practices. }\end{array}$ \\
\hline Expert (B2) & $\begin{array}{l}\text { uses a range of digital technologies confidently, } \\
\text { creatively, purposefully; selects digital } \\
\text { technologies for particular situations, is curious } \\
\text { and open to new ideas. Should continue critically } \\
\text { developing his/her digital strategies. }\end{array}$ \\
\hline Leader (C1) & $\begin{array}{l}\text { continuously reflects on and further develops } \\
\text { his/her practices, exchanges with peers new ideas } \\
\text { and helps other lecturers seize the potential of } \\
\text { digital technologies for enhancing teaching and } \\
\text { learning. Should experiment a bit more. }\end{array}$ \\
\hline Pioneer (C2) & $\begin{array}{l}\text { experiments with highly innovative and complex } \\
\text { digital technologies and develops novel } \\
\text { pedagogical approaches. He/she leads innovation } \\
\text { and is a role model for other lecturers. }\end{array}$ \\
\hline
\end{tabular}

Source: [7]

To assess the curriculum content of the teacher training programs, relevant course documents have been collected as well as the additional information on the content and aims of the $\mathrm{PhD}$ programs.

\section{Results}

The survey results indicate that the highest scores were demonstrated by $\mathrm{PhD}$ students of Environmental Engineering specialization. However, Biotechnology and Animal Sciences specializations also had good results in areas of Digital Resources, Teaching and Learning, and Empowering Learners. Obtained results could be substantiated by the content of the $\mathrm{PhD}$ programs on these specializations which offer different engineering courses and allows students to gain technological digital skills (Figure 2). 


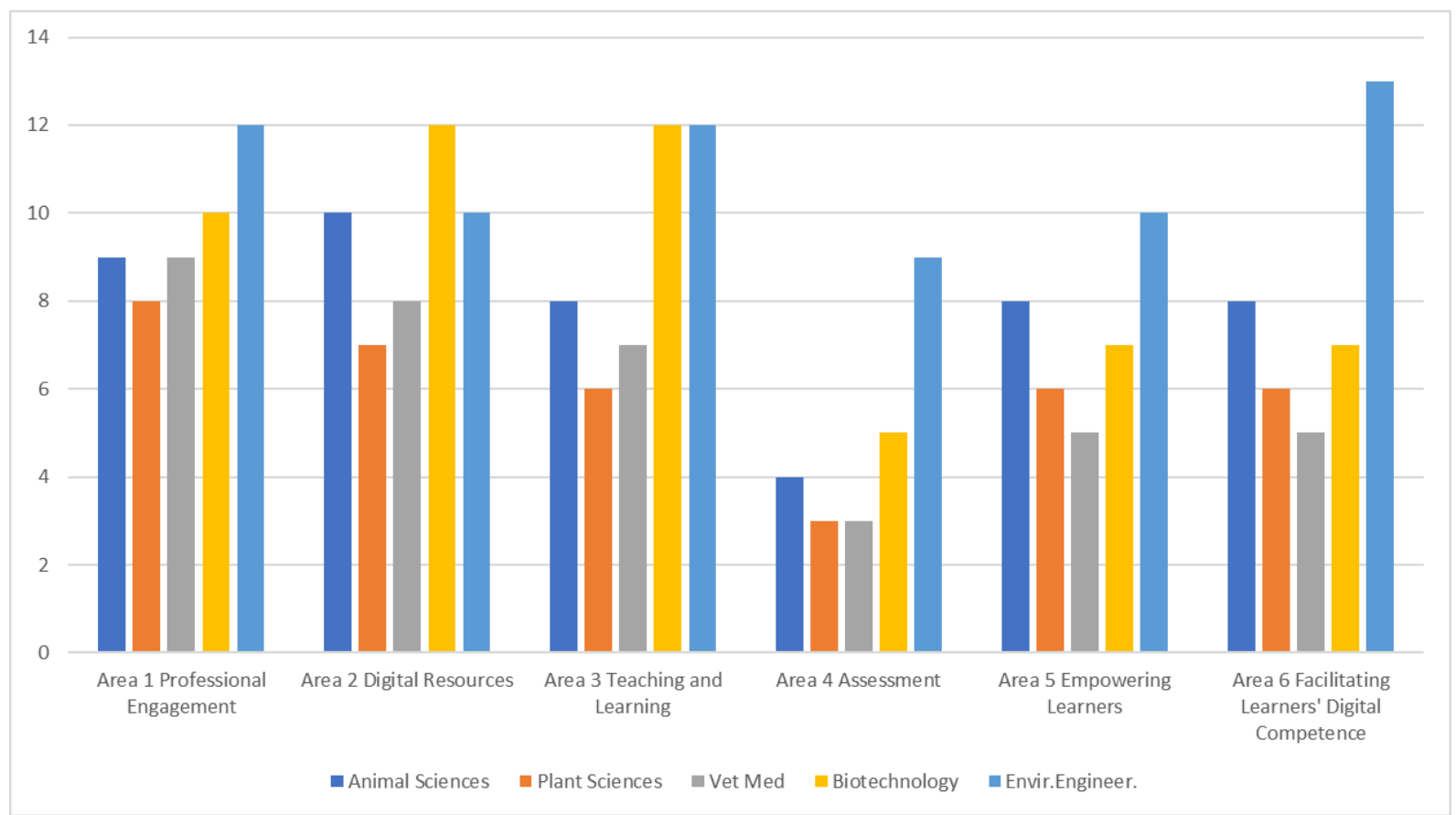

Figure 2. Analysis of the $\mathrm{PhD}$ students' levels of digital competencies per areas according to the specializations

In the same time, $\mathrm{PhD}$ students of all specializations demonstrated low scores in the area of assessment. It means that they didn't feel confident in using digital technologies and strategies to enhance assessment and need additional preparation for this teaching activity. Generally, competencies that are more at the core of digital teaching (using digital tools for communication, selecting digital resources, integration of digital resources into teaching, facilitating learners' digital competence) had higher average scores in the study sample. Critical competences with low average scores were those that are more advanced and need additional efforts from the $\mathrm{PhD}$ students as future teachers (digital content creation, assessment, empowering learners).

A pilot diagnostic test concerning stages of $\mathrm{PhD}$ students digital competencies allows to state that more than half of the respondents scored Explorer A2 (44\%) and Integrator B1 (31\%) stages in the examined range of them (Table 3). About a third of respondents showed Expert B2 (25\%) stage of digital competencies and the highest competence level, C2, was left out.

Assessment of the curriculum content of the $\mathrm{PhD}$ programs at Wroclaw University of Environmental and Life Sciences showed that there were no specific pedagogical courses on the topic of Digital Technologies in Teaching and Learning. The university offers just one $\mathrm{PhD}$ training pedagogical course "Pedagogy with the Basic of Didactic" and the issue concerning ICT techniques in teaching and learning is only one topic integrated into this course. This finding confirms the need to rethink $\mathrm{PhD}$ students teacher training programs and focus on the early stage academic teachers' professional development towards different areas of digital competence.

\section{Discussion and Conclusions}

Our respondents confirmed the results of other authors $[4,21]$ about the importance of integrating digital technologies into teachers' training programs. The study indicated that preparation for using digital techniques should be included in different courses of $\mathrm{PhD}$ programs. Unfortunately, attention is mainly focused on technical issues without practical introduction and training pedagogical digital skills for teaching and learning (e.g. using digital technologies for communication, collaboration and professional development, sourcing, creating and sharing digital resources, managing and orchestrating the use of digital technologies in teaching and learning, using digital technologies and strategies to enhance assessment, to enhance inclusion, personalization, and learners' active engagement, enabling learners to creatively and responsibly use digital technologies for information, communication, content creation, well-being and problem-solving, etc.). Apart from the strictly technical teaching skills connected with the use of various devices (interactive boards, laptops, tablets), it is immensely important to raise teachers' awareness regarding the purposefulness of the application of technology in education.

Teachers and students-teachers often feel that they are not sufficiently well equipped for teaching and learning with technology in their classrooms [1, 12, 13, 22]. Students future teachers were rather unprepared to use ICT in pedagogical practice [14]. There is a gap between 
the digital demands that newly qualified teachers meet in their profession and the training in using instructional technology provided during teacher education [11]. Some authors have revealed that workshops and courses that are intended to improve the pedagogical use of ICT in teacher education do not have the desired effect [20, 21]. To implement more pedagogic and embedded use of ICT, both policies and practices have to move beyond basic digital skills and use of ICT as a tool, to find ways of building the interpretive and creative potential of ICT into teacher training [5].

There is a need to conduct comparative international research aimed at finding and implementing the best practices of $\mathrm{PhD}$ students' digital competence training programs including various ways of developing student skills for making better use of digital technology for teaching and learning, developing relevant digital competencies and skills for the digital transformation, improving education through better data analysis and foresight.

\section{REFERENCES}

[1] A.T., Ottenbreit-Leftwich, K.D., Glazewski, T.J., Newby, \& P.A., Ertmer. Teacher value beliefs associated with using technology: Addressing professional and student needs. Computers \& Education, 55(3), 2010, 1321-1335.

[2] A., Tarkowski, \& M., Plebańska. The Digitalisation of Polish Education, 2019. Accessed March 10, 2020. https://ngoteka.pl/bitstream/handle/item/367/cyfryzacja-pol skiej-edukacji_final_EN.pdf?sequence $=1$

[3] B.H. Benton-Borghi. A universally designed for learning (UDL) infused Technological pedagogical content knowledge (TPACK) practitioners' model essential for teacher preparation in the 21st century. Journal of Educational Computing Research, 48(2), 2013, 245-265.

[4] C., Kivunja. Embedding Digital Pedagogy in Pre-Service Higher Education. To Better Prepare Teachers for the Digital Generation. International Journal of Higher Education Vol. 2, No. 4, 2013, 131-142.

[5] C., Tømte, E., Hovdhaugen, \& N.H. Solum. ICT in initial teacher training. Country report, Norway. Oslo: OECD, 2009.

[6] Cedefop. Terminology of European education and training policy: a selection of 130 terms. Luxembourg: Publications Office, 2014, Available at http://www.cedefop.europa.eu/en /eventsand-projects/projects/validation-non-formal-andinfor mal-learning/european-inventory/european-inventory-gloss ary.

[7] Digital Competence Framework for Educators (DigCompEdu). The European Commission's science and knowledge service. Accessed October 30, 2018. https://ec.europa.eu/jrc/en/digcompedu

[8] E.J., Byker, S.M., Putman, D., Polly, \& L., Handler. Examining elementary education teachers and preservice teachers' self-efficacy related to technological pedagogical and content knowledge (TPACK). In C. B. Hodges (Ed.), Self-Efficacy in instructional technology contexts. Statesboro, GA, USA: Springer, 2018, 119-140.

[9] F.A., Inan, \& D.L., Lowther. Factors affecting technology integration in K-12 classrooms: a path model. Educational Technology Research and Development, 58(2), 2010, 137154.

[10] F., Deng, C.S., Chan, C.C., Tsai, \& M.H., Lee. The relationships among Chinese practicing teachers' epistemic beliefs, pedagogical beliefs, and their beliefs about the use of ICT. Journal of Educational Technology \& Society, 17(2), 2014, 245-256.

[11] G.B., Gudmundsdottir, M., Loftagarden, \& G.Ottestad. Newly qualified teachers. Professional digital competence and experiences with ICT in teacher education, 2014.

[12] G., Sang, M., Valcke, J., Van Braak, \& J., Tondeur. Student teachers' thinking processes and ICT integration: Predictors of prospective teaching behaviors with educational technology. Computers \& Education, 54(1), 2010, 103-112.

[13] J., Tondeur, L. H., Kershaw, R., Vanderlinde, \& J., Van Braak. Getting inside the black box of technology integration in education: Teachers' stimulated recall of classroom observations. Australasian Journal of Educational Technology, 29(3), 2013, 434-449.

[14] J., Twidle, P., Sorensen, A., Childs, J., Godwin, \& M., Dussart. Issues, challenges, and needs of student science teachers in using the Internet as a tool for teaching. Technology, Pedagogy, and Education, 15(2), 2006, 207 221.

[15] Key Data on Learning and Innovation through ICT at School in Europe 2011. Accessed October 20, 2018. http://eurydice.org.pl/wp-content/uploads/2014/10/129EN.p $\mathrm{df}$

[16] L.S. Shulman. Knowledge and teaching: Foundations of the new reform. Harvard Educational Review, 57(1), 1987, $1-$ 22.

[17] M.J., Koehler, \& P., Mishra. What happens when teachers design educational technology? The development of technological pedagogical content knowledge. Journal of Educational Computing Research, 32(2), 2005, 131-152.

[18] M.L. Niess. Investigating TPACK: Knowledge growth in teaching with technology. Journal of Educational Computing Research, 44(3), 2011, 299-317.

[19] M.J., Koehler, P., Mishra, \& W., Cain. What is Technological Pedagogical Content Knowledge (TPACK)? Journal of Education, 193(3), 2013, 13-19.

[20] R.H., Kay. Evaluating strategies used to incorporate technology into preservice education: A review of the literature. Journal of Research on Technology in Education, 38(4), 2006, 383-408.

[21] S., Ruhalahti, A.M., Korhonen, P., Rasi. Authentic, dialogical knowledge construction: a blended and mobile teacher education program. Educational Research, 59, No. 4, 2017, 373-390.

[22] W. R., Houston, \& M. E., Pierson. Preparing teachers for a global society that is yet unknown to teacher educators. 
Teacher Education and Practice, 21(4), 2008, 479-481.

[23] Y. J., Joo, S., Park, \& E., Lim. Factors influencing pre-service teachers' intention to use technology: TPACK, teacher self-efficacy, and technology acceptance model. Journal of Educational Technology \& Society, 21(3), 2018, $48-59$.

[24] Y.-H., Chen \& S.-J. Jang. Exploring the relationship between self-regulation and TPACK of Taiwanese secondary in-service teachers. Journal of Educational Computing Research, 2019, 57.4: 978-1002. 